\title{
Petrogeothermal energy resources within low-temperature areas of Iceland
}

\author{
Anna Sowiżdżał, Anna Drabik \\ AGH University of Science and Technology, Faculty of Geology, Geophysics and Environmental Protection, \\ Department of Fossil Fuels; al. Mickiewicza 30,30-059 Krakow, Poland; e-mail: adrabik@agh.edu.pl, ansow@agh.edu.pl
}

(C) 2016 Authors. This is an open access publication, which can be used, distributed and reproduced in any medium according to the Creative Commons CC-BY 4.0 License requiring that the original work has been properly cited.

Received: 2017-01-04; accepted: 2017-02-14

\begin{abstract}
Iceland remains one of the leading countries in the field of the utilization of geothermal energy worldwide. Despite its knowledge and tremendous experience in the exploitation of mostly high-temperature geothermal energy resources (water and steam), it has been interested in the possibility of harnessing heat from hot rock formations with the implementation of the Enhanced Geothermal System (EGS). This paper presents the main outcomes of the feasibility study of EGS technology within the low-temperature area of the country. It includes broad geological research that constitutes the background for finding a suitable site for an EGS installation and to determine the local thermal parameters together with rock characteristics. To calculate the amount of heat stored within the preordained HDR formation and ascertain that the deployment of the EGS within the lowtemperature area of Hólmavík town (NW Iceland) is plausible, the term of static resources of energy was applied. Considering the geological issue, it emerged that within the low-temperature areas of Iceland, there are excellent lithological (mainly porous lava layers) as well as thermal conditions (relatively high heat flow and geothermal gradient values) for the implementation of EGS technology for providing heat for small district heating networks. The amount of energy stored within the designed rock formation turned out to be significant and more than sufficient to cover the energy demands of Hólmavík town. The authors also emphasize the importance of running several exchange programs between Polish and Icelandic research and academic centers, with the indication of possible benefits for the Polish geothermal energy sector.
\end{abstract}

Keywords: Iceland, geothermal energy, low-temperature area, static resources, geology, Enhanced Geothermal System (EGS), Hólmavík

\section{INTRODUCTION}

Iceland has become one of the world-leaders in term of harnessing renewable energy, with its abundant geothermal resources together with hydropower currently supplying almost 100\% of electricity generation and $86 \%$ of primary energy use (Orkustofnun 2016). Due to its location at the spreading center of the Mid-Atlantic Ridge and Icelandic Hot Spot, Iceland is clearly endowed with an abundant amount of geothermal resources (Kranz 2006). Geothermal resources are divided into low-temperature and high-temperature systems. The low-temperature resources are defined to have a reservoir temperature below $150^{\circ} \mathrm{C}$ at the depth of $1 \mathrm{~km}$, whereas, the high-temperature resources have a temperature above 150$200^{\circ} \mathrm{C}$ (Axelsson et al. 2010, Björnsson 2011). According to Ragnarsson (2015), geothermal energy extracted from both low-temperature and hightemperature fields covers $68 \%$ of the primary energy supply of the country (about $140 \mathrm{PJ}$ ), used for direct purposes (mainly low-temperature resources) as well as electricity generation (hightemperature resources). Therefore, it seems obvious that geothermal energy plays a significant role 
in the Icelandic energy supply sector (Ragnarsson 2015). Space heating remains the principle direct utilization of geothermal energy, covering more than $90 \%$ of the energy used to heat buildings (Axelsson et al. 2010). Moreover, it is directly used in other sectors such as bathing, snow melting, greenhouses and aquaculture, as well as for industrial applications. Nevertheless, the present utilization of geothermal resources in Iceland is considered a tiny part of what those resources can provide (Björnsson 2011). Therefore, beyond the utilization of geothermal waters and steam, Iceland is interested in the possibility of using the energy stored in formations of hot dry rock (HDR), placed mainly within the low-temperature areas of the country.

For many years, the Department of Fossil Fuels of the AGH University of Science and Technology in Cracow has collaborated with various academic and research centers from Iceland. Since 2013, the FSS Program - the Scholarship and Training Fund Mobility Projects in Higher Education, financed from the Norwegian funds, has been realized providing the possibility of running students and employees exchange programs with Keilir Institute of Technology (Reykjanesbær, Iceland). In 2016, two students taking a degree in the field of renewable energy resources at the Faculty of Geology, Geophysics and Environmental Protection of the AGH UST, finished their M. Sc. diploma semester at the Keilir Institute of Technology (KIT) working on the project Feasibility study of Enhanced Geothermal System (EGS) in low-temperature areas of Iceland with Hot Dry Rock (HDR), in cooperation with the students and employees of KIT. Within this unique project, the case study of low-temperature resource utilization in Hólmavík town area (NW Iceland) with the implementation of the Enhanced Geothermal System (EGS) was performed. The main target was to verify the possibility of using the energy stored in HDR within the analyzed area to provide heat for a small district heating network.

The participation in projects implemented by Icelanders allows the transfer of valuable geothermal experience to Polish circumstances. Despite the different geological conditions in both countries, this project fits the Polish context perfectly as it determines the possibilities of geothermal resource utilization. It concerns the possibility of using low-temperature geothermal resources with the EGS systems implementation, which is also a novelty in Iceland due to the occurrence of large areas of high-temperature hydrogeothermal resources that are utilized in a large scale for various purposes (Drabik et al. 2016). Current utilization of geothermal energy in Poland is related only to resources of geothermal water, and is managed in different sectors (Tomaszewska \& Hołojuch 2011, Gancarz 2015, Górecki et al. 2015, Korzec 2016). Nevertheless, for several years the development of energy accumulated in hot dry rock (petrogeothermal resources) remains the subject of the comprehensive research (Sowiżdżał et al. 2013, Wójcicki et al. 2013, Bujakowski et al. 2015, Sowiżdżał 2016, Sowiżdżał \& Kaczmarczyk 2016, Sowiżdżał \& Semyrka 2016).

\section{BACKGROUND - THE GEOLOGY OF THE HÓLMAVÍK TOWN AREA}

Iceland is located astride the Mid-Atlantic Ridge, which is a divergent boundary between the North American and the Eurasian plates. This plate boundary is an active one where tectonic plates are being pulled apart by the forces of the plate motions with the spreading rate of about $2 \mathrm{~cm}$ per year (i.e. $1 \mathrm{~cm}$ per year in each direction). The surface expression of this phenomenon is the belt of active faulting and volcanism which runs across the country, beginning at the Reykjanes Peninsula in the Southwest and extends to Öxarfjördur in the North (Fig. 1). Geologically, Iceland is the youngest area of the European continent as all the rocks were formed during the last 25 million years. If the age of the Earth (4.5 billion years) is referred to be one year, then Iceland has existed for only two days, the first regional glaciation has occurred five hours ago, and passed merely one minute ago beginning the youngest epoch - the Holocene (Thordarson 2012). This island is built up from rocks that were formed during the Tertiary and the Quaternary. Based on the climatic evidences, four stratigraphic groups or series are distinguished from among aforementioned periods; they are as following (Sæmundsson 1979): 
- The Tertiary - older than 3.1 million years;

- Plio-Pleistocene - from 0.7 to 3.1 million years;

- Upper Pleistocene - back to 0.7 million years;

- Postglacial - last 9,000 to 13,000 years.

The area of research - the Hólmavík town - is located in the north-western part of Iceland at latitudes $65^{\circ} 43^{\prime} \mathrm{N}$ and longitudes $21^{\circ} 41^{\prime} \mathrm{W}$, exactly by the Steingrímsförður (Fig. 1). With a population of 341 people, it remains the second biggest town, after Isafjörður, in the Westfjords region.

Hólmavík town is located in the Tertiary Basaltic Formation - the oldest part of the lava pile in Iceland (older than 3.1 mya) (Sæmundsson 1979). As the growth of the lava pile proceeded from NW to $\mathrm{SE}$, the lavas become progressively younger closer to the axial rift zone. Thus, it is possible to say that Hólmavík is located on the younger part of the Tertiary bedrock. The general structure of the Northwest Peninsula is rather simple, as basaltic lavas dip at low south-easterly angles, indicating a structural dome (McDougall et al. 1984). However, steeper dips at angle of $10-15^{\circ}$ appear in the flexure extending from the Breidafjördur to the Steingrimsfjördur with lava layers also becoming thicker as they dip down. The network of faults orientated along the NE-SW line determine the local tectonics. Nonetheless, small-scale tectonics may change significantly, due to different stress pattern occurring within variable kind of rock formations. The geological studies concerning the Northwest Peninsula have proven that there is a high similarity between these and those mapped in eastern Iceland lava types (ISOR 2016). The Tertiary Basalt Formation consists predominantly of rocks of volcanic origin (more than $85 \%$ ) and was formed in the volcano-tectonic processes occurring in the currently active volcanic belts. Therefore, it has identical geological components to the active volcanic zones and consists mainly of tholeiite, olivine tholeiite, porphyritic basalt, and intermediate as well as acidic lavas. From 10\% to $15 \%$ of the Tertiary Basalt Formation is taken by sedimentary rocks such as: red baked soil (interbeds), lacustrine siltstones and fluvial gravels. Although they make up only a few percent, they are an important component due to the fact they preserve information about environment and climate changes. The most conspicuous are the red interbeds - ancient soils with a characteristic rusty-red or red-brown color which is an effect of chemical weathering in the warm and humid climate of the Tertiary period. The most popular type of interbeds in the Tertiary formation occur as thin layers of clayish or tuffaceous material that is made of opaque groundmass and volcanic glass. It is common for these ancient soils to contain occasional lignite and different genera of fossil plants like e.g. leaf imprints, pollen grains, fruit, seeds and tree moulds (Sæmundsson 1979, McDougall et al. 1984, Thordarson 2012).

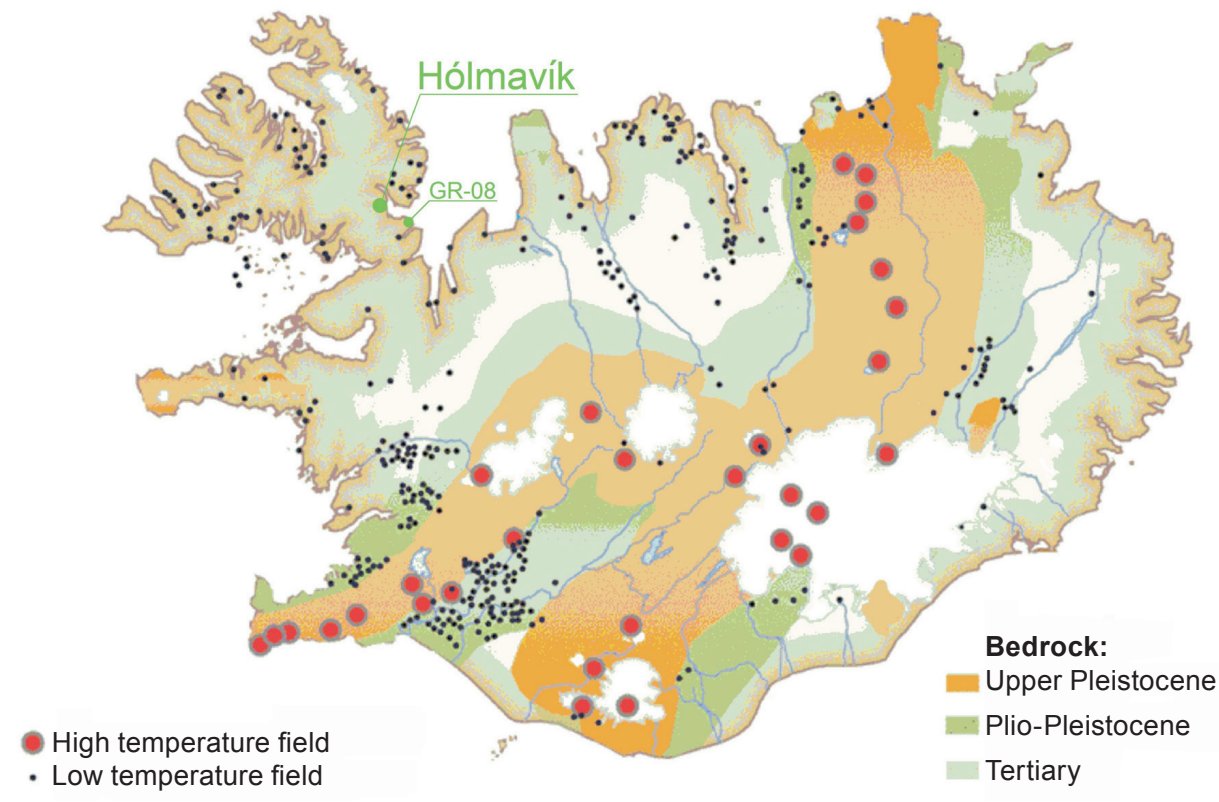

Fig. 1. Simplified geology and geothermal fields within Iceland; modified after Björnsson (2011) 


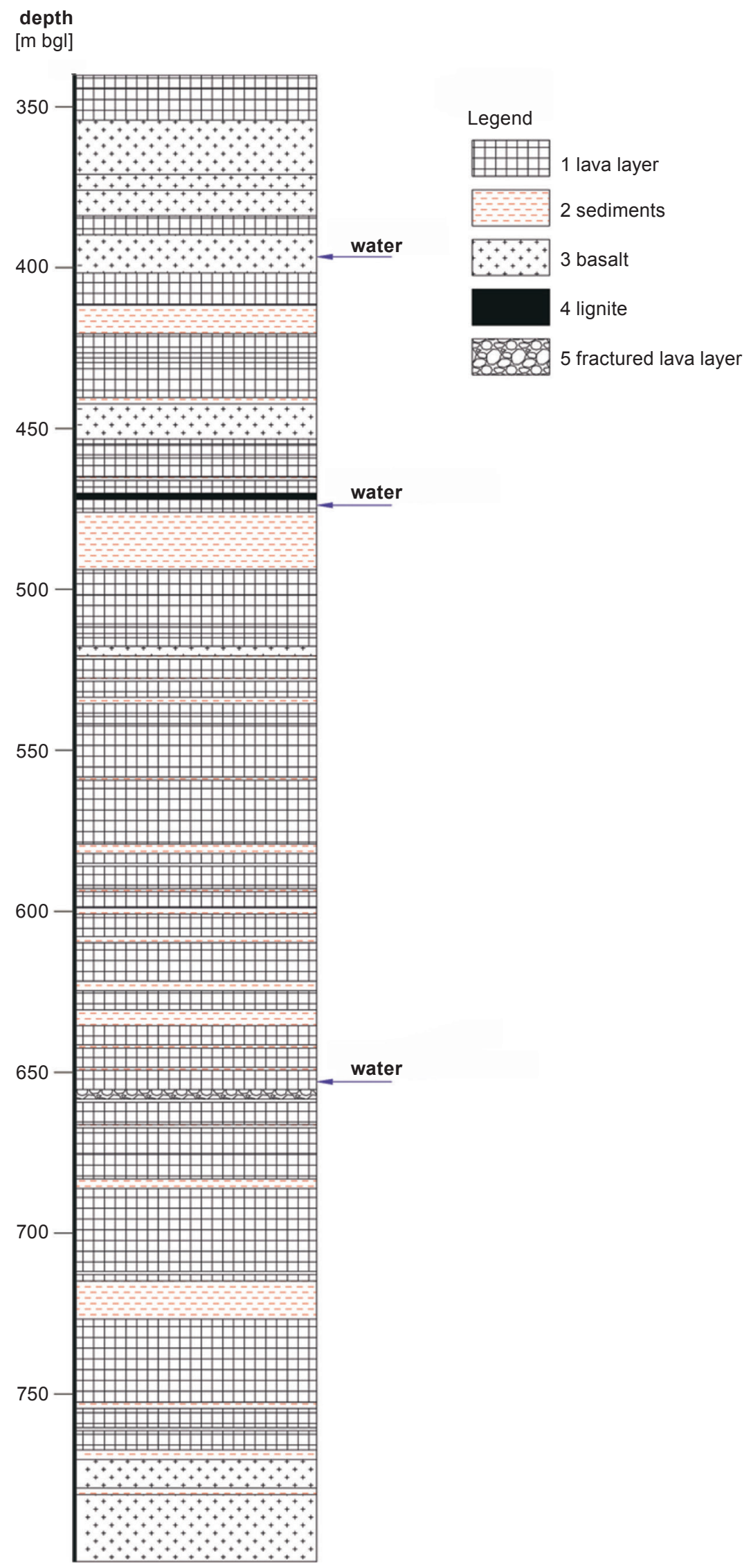

Fig. 2. The simplified profile of the GR-08 well; based on Samundsson \& Björnsson (2002) 
Whereas the above information concerns the geology of the whole NW Peninsula, the local geology of the Hólmavík town area was needed. It was decided that an effective area of research was within a radius of $20 \mathrm{~km}$ of Hólmavík town. For this reason, Orkustofnun - the Icelandic National Energy Authority was asked to provide drilling reports from boreholes in proximity to Hólmavík and thus reports from 32 boreholes became a subject of the further research. Whereas the vast majority of obtained reports concern shallow wells no deeper than 50 meters below the surface, the report of the GR-08 well (Fig. 2) was found to be the most valuable. As a result, it was taken as the basis for the further development of EGS in the Hólmavík town area.

The GR-08 well is a directional borehole that is located $18 \mathrm{~km}$ east of Hólmavík town (Fig. 1). It was drilled in 2001 to a depth of 1,104 meters, where the first $500 \mathrm{~m}$ goes directly down, then the well turn towards west side. This means that the bottom hole is about $60-70 \mathrm{~m}$ west of the top of the well. Unfortunately, in the GR-08 well, there was inadequate water flow and, what is more, the GR-08 well turned out to be clogged at the depth of $925 \mathrm{~m}$, thus the last $179 \mathrm{~m}$ remained inaccessible for measurements. The report of the GR-08 well obtained from the Orkustofnun consists of data only to the aforementioned depth. The developed profile of the GR- 08 well can be seen below (Fig. 2) As mentioned earlier, the area of Hólmavík town is mainly built up from lava layers. They are described as fine-grained and the color ranges from red (oxidized layers) to black. According to McDougall et al. (1984) they have a petrographic composition primarily of tholeiite or olivine tholeiite. In addition, basaltic rocks can be observed within the well profile (Fig. 2), however only in a small quantity. As it can be noticed, three thick layers of sediments (intermediate layers) occur at the depths of about $410 \mathrm{~m}, 475 \mathrm{~m}$ and $720 \mathrm{~m}$. Furthermore, numerous thinner intermediate layers are placed within the GR-08 well profile and a lignite stratum is reported at a depth of about $470 \mathrm{~m}$ below the surface. It is worth emphasizing the distribution of a strongly fractured lava layer $655 \mathrm{~m}$ below the surface, as well as the numerous fissures at the depth of $500 \mathrm{~m}$, but they are imitatively filled. It is important to notice that there is no porosity mentioned in the report but rather vesicular layers - closed porosity occurs (Sæmundsson \& Björnsson 2002).

\section{THE DETERMINATION OF THE EGS RESERVOIR}

Generally, Hólmavík town is located within the low-temperature area (Fig. 1) which according to Kranz (2006) and Björnsson (2011) means that the geothermal gradient is expected to be a value from the range of $50^{\circ} \mathrm{C} / \mathrm{km}$ and $150^{\circ} \mathrm{C} / \mathrm{km}$. Analyzing the given geothermal gradient charts for wells: PV-01, HR-06, YÓ-04 and YÓ-05, located in the direct vicinity of Hólmavík town (a distance of about $5 \mathrm{~km}$ ), it became apparent that the geothermal gradient for this area varies from $60^{\circ} \mathrm{C} / \mathrm{km}$ to $68^{\circ} \mathrm{C} / \mathrm{km}$ (Sæmundsson 1999). However, all of these wells only go down to $50 \mathrm{~m}$, which is not enough, and present a conductive type of heat transmission. In contrast, the GR-08 well goes $1,104 \mathrm{~m}$ down and has a measured geothermal gradient to the depth of $925 \mathrm{~m}$. Obviously, the geothermal gradient changes with depth, which is caused by an adjustment in dominating heat transmission. Thus, the geothermal gradient values down the GR-08 well profile are diversified; geothermal gradients together with a way of heat transmission for each of the definite intervals are presented in Table 1.

The average heat flow in the analyzed area fluctuates from $100 \mathrm{~mW} / \mathrm{m}^{2}$ to $150 \mathrm{~mW} / \mathrm{m}^{2}$, whereas the mean value for the country was established as $175 \mathrm{~mW} / \mathrm{m}^{2}$ (Hjartarsson 2015).

\section{Table 1}

Geothermal gradients in definite depth intervals for the GR-08 well; based on Semundsson \& Björnsson (2002)

\begin{tabular}{|c|c|l|}
\hline $\begin{array}{c}\text { Depth below } \\
\text { the surface }[\mathbf{m}]\end{array}$ & $\begin{array}{c}\text { Geothermal } \\
\text { gradient } \\
{\left[{ }^{\circ} \mathbf{C} / \mathbf{k m}\right]}\end{array}$ & $\begin{array}{c}\text { Dominating way of } \\
\text { heat transmission }\end{array}$ \\
\hline $0-400$ & 132.5 & conductivity \\
\hline $400-550$ & 200.0 & $\begin{array}{l}\text { mixed: conductivity/ } \\
\text { convection }\end{array}$ \\
\hline $550-925$ & 45.0 & convection \\
\hline
\end{tabular}

Since finding a suitable location for the EGS reservoir is of vital importance (Olasolo at al. 2016), the Hólmavík area was studied as far as it 
was possible. However, as the EGS technology is still developing, it is not easy to determine just what a "suitable site" means. Therefore, it is important to choose a location on the basis of previous studies, in particular geological as well as geochemical and numerical ones. Hence, the ground must have an appropriate (for heat and/or electricity production) geothermal gradient, the rock formation needs to have sufficient properties and the depth of probable reservoir must be considered drillable (Olasolo et al. 2016). Thereupon, the lithological profile (Fig. 2) together with the geothermal gradient chart of the GR-08 well (Tab. 1) were studied so that the suitable depth interval could be determined.

Considering the temperatures, the most prospective for geothermal usage is a site where the convective geothermal gradient dominates and in this case, it is at a depth of $550 \mathrm{~m}$. As the geothermal gradient in this section is significantly lower $\left(\sim 45^{\circ} \mathrm{C}\right)$ than in the overburden $\left(\sim 200^{\circ} \mathrm{C}\right)$, deeper drilling does not necessarily seem to be economically justified. Simultaneously, analyzing the lithographic profile, it is noticeable that at the nearby depth (655 $\mathrm{m}$ below the surface), a strongly fractured lava layer with the appearance of water is reported. Taking into consideration the above aspects, the prospective geothermal reservoir for an EGS application was determined for the rock complex between the depth of $630 \mathrm{~m}$ and $710 \mathrm{~m}$ (Fig. 2).
It is important to mention that above and beneath the prospective depth interval, thick layers of sediments are located that are considered-to-be cap rocks.

On the base of the rock complex within the definite depth interval, three groups of rocks were distinguished: lava layer, fractured lava layer and sediments. As intermediate layers in Westfjords area consist mainly of red, baked soil and authors (Sæmundsson \& Björnsson 2002) of the GR-08 well report emphasized the red color of interbed layers, altogether sediments were taken as "redbeds". Also, as it was presented by McDougall (1984), lava layer has a composition approximate to basalt and thus the properties of dense basalt constituted the basis for the characteristics of the lava layers. The assumptions for its parameters (specific heat, density, porosity) were designated on the basis of a literature review and several consultations with employees of the Iceland Geosurvey (ISOR). Furthermore, these values were used to determine the basic physical properties of the designed depth interval - a weighted average specific heat and density. The results of the calculation can be seen in Table 2 .

As there was no information about the permeability of the rock formation within the definite area, after consultation with members of the Iceland Geosurvey (ISOR 2016), it was taken to be a value from the scope of $2-5 \mathrm{mD}$.

Table 2

Parameters for the designed EGS reservoir

\begin{tabular}{|l|c|c|c|c|c|}
\hline \multicolumn{1}{|c|}{ Parameter } & Dense basalt & Sediments & Lava layer & $\begin{array}{c}\text { Fractured } \\
\text { lava layer }\end{array}$ & $\begin{array}{c}\text { Mean value for } \\
\text { the interval }\end{array}$ \\
\hline Density $\left[\mathrm{kg} / \mathrm{m}^{3}\right]$ & 3,300 & 2,820 & 2,970 & 2,640 & 2,943 \\
\hline Specific heat $\left[\mathrm{J} /\left(\mathrm{kg} \cdot{ }^{\circ} \mathrm{C}\right)\right]$ & 850 & 1,044 & 1,187 & 1,524 & 1,185 \\
\hline
\end{tabular}

\section{STATIC ENERGY RESOURCES}

\section{Methodology and assumptions}

The methodology is based on the term of the static resources and the technical possibilities to extract them. It allows us to check different hypothetical scenarios for the utilization of petrogeothermal energy, as well as to determine the responded dimensions of the reservoir. The methodology developed at the Department of Fossil Fuels, AGH
University of Science and Technology was employed (Górecki et al. 2006, 2015). It is based on the principles of geothermal resource assessment used in European Union countries (Haenel \& Staroste 1988, Hurter \& Haenel 2002) and calculating the geothermal energy resources on the basis of a volumetric calculation model (Muffler \& Cataldi 1978).

Static resources of energy accumulated in HDR formation are defined as the total amount 
of heat stored in free water hosted within the pores, fractures and in the rock framework of the definite reservoir (Górecki \& Hajto 2006), so it is all of the available heat content within HDR formation.

Petrogeothermal resources are mostly related to the energy accumulated in rocks, and parameters of waters occurring there in small quantities are less important. Media (usually water) introduced through wells into heated rock formations (HDR) are heat carriers in systems that utilize this type of energy. For this reason, the resource assessment refers only to energy accumulated in the rocks (Sowiżdżał 2016).

Static resources of designed HDR formation can be calculated on the base of the equation (1):

$E_{Z S}=A \cdot d \cdot C_{p} \cdot \rho \cdot\left(T_{0}-T_{i}\right)$

where:

$A$ - area of reservoir $\left[\mathrm{m}^{2}\right]$,

$d$-thickness of reservoir [m],

$\mathrm{C}_{p}$-specific heat of formation $\left[\mathrm{J} /\left(\mathrm{kg} \cdot{ }^{\circ} \mathrm{C}\right)\right]$,

$\rho$-formation density $\left[\mathrm{kg} / \mathrm{m}^{3}\right]$,

$T_{0}$ - mean initial formation temperature $\left[{ }^{\circ} \mathrm{C}\right]$,

$T_{i}$-application injection temperature $\left[{ }^{\circ} \mathrm{C}\right]$.

To proceed with the calculations, after researching the geothermal reservoir dimensions the area of reservoir was established cautiously at $10 \mathrm{~km}^{2}$ (Tómasson \& Arnarsson 2000, Brown et al. 2012). In addition, the reservoir was considered to be a cylindrical shape with a thickness of $80 \mathrm{~m}$. Based on the literature research, the supply/return temperature of low-temperature district heating was set at $55 / 25^{\circ} \mathrm{C}$ ( $\mathrm{Li} \&$ Svendsen 2012). Nevertheless, when the loss of temperature during fluid transmission was included, the return (injection) temperature was considered to be about $20^{\circ} \mathrm{C}$. As the geothermal gradient chart of the GR-08 well shows (Tab. 1), the average temperature of the definite interval was taken to be $100^{\circ} \mathrm{C}$ (Sæmundsson \& Björnsson 2002) and set to be constant during the reservoir lifetimes. Using the aforementioned values and assumptions relevant to the rock sequence (Tab. 2), and also assessing the reservoir's conditions to be constant, the static resources of the designed reservoir $\left(E_{\mathrm{zs}}\right)$ can be determined.

However, the resources available in spite of the technical limitations are called technical resources. In this case, the basic rate of utilization was cautiously estimated at $1 \%$ of static resources, as Tester (2006) gives that at least $2 \%$ of the total resources stored within HDR that may be extracted. Technical resources were also calculated for hypothetical $5 \%, 10 \%, 25 \%$ and $40 \%$ rates of energy extraction (Tab. 3).

Table 3

The sufficiency of the designed EGS reservoir

\begin{tabular}{|c|c|c|c|c|c|c|}
\hline $\begin{array}{c}\text { Energy } \\
\text { recovery } \\
\text { rate [\%] }\end{array}$ & $\begin{array}{c}\text { Time of } \\
\text { exploitation } \\
\text { [years] }\end{array}$ & $\begin{array}{c}\text { Energy } \\
\text { demand } \\
{[\mathrm{kWh}]}\end{array}$ & $\begin{array}{c}\text { Static } \\
\text { resources } \\
E_{\mathrm{zs}}[\mathrm{J}]\end{array}$ & $\begin{array}{c}\text { Reservoir } \\
\text { volume } \\
V\left[\mathrm{~km}^{3}\right]\end{array}$ & $\begin{array}{c}\text { Reservoir area } \\
A\left[\mathrm{~km}^{2}\right]\end{array}$ & $\begin{array}{c}\text { Reservoir } \\
\text { radius } \\
R[\mathbf{k m}]\end{array}$ \\
\hline \multirow{3}{*}{1} & 50 & $3.745 \mathrm{E}+10$ & $1.348 \mathrm{E}+17$ & $4.831 \mathrm{E}-01$ & $6.039 \mathrm{E}+00$ & $1.387 \mathrm{E}+00$ \\
\hline & 30 & $2.247 \mathrm{E}+10$ & $8.089 \mathrm{E}+16$ & $2.899 \mathrm{E}-01$ & $3.624 \mathrm{E}+00$ & $1.074 \mathrm{E}+00$ \\
\hline & 25 & $1.872 \mathrm{E}+10$ & $6.741 \mathrm{E}+16$ & $2.416 \mathrm{E}-01$ & $3.020 \mathrm{E}+00$ & $9.806 \mathrm{E}-01$ \\
\hline \multirow{3}{*}{5} & 50 & $7.490 \mathrm{E}+09$ & $2.696 \mathrm{E}+16$ & $9.663 \mathrm{E}-02$ & $1.208 \mathrm{E}+00$ & $6.202 \mathrm{E}-01$ \\
\hline & 30 & $4.494 \mathrm{E}+09$ & $1.618 \mathrm{E}+16$ & $5.798 \mathrm{E}-02$ & $7.247 \mathrm{E}-01$ & $4.804 \mathrm{E}-01$ \\
\hline & 25 & $3.745 \mathrm{E}+09$ & $1.348 \mathrm{E}+16$ & $4.831 \mathrm{E}-02$ & $6.039 \mathrm{E}-01$ & $4.386 \mathrm{E}-01$ \\
\hline \multirow{3}{*}{10} & 50 & $3.745 \mathrm{E}+09$ & $1.348 \mathrm{E}+16$ & $4.831 \mathrm{E}-02$ & $6.039 \mathrm{E}-01$ & $4.386 \mathrm{E}-01$ \\
\hline & 30 & $2.247 \mathrm{E}+09$ & $8.089 \mathrm{E}+15$ & $2.899 \mathrm{E}-02$ & $3.624 \mathrm{E}-01$ & $3.397 \mathrm{E}-01$ \\
\hline & 25 & $1.872 \mathrm{E}+09$ & $6.741 \mathrm{E}+15$ & $2.416 \mathrm{E}-02$ & $3.020 \mathrm{E}-01$ & $3.101 \mathrm{E}-01$ \\
\hline \multirow{3}{*}{25} & 50 & $1.498 \mathrm{E}+09$ & $5.393 \mathrm{E}+15$ & $1.933 \mathrm{E}-02$ & $2.416 \mathrm{E}-01$ & $2.774 \mathrm{E}-01$ \\
\hline & 30 & $8.988 \mathrm{E}+08$ & $3.236 \mathrm{E}+15$ & $1.160 \mathrm{E}-02$ & $1.449 \mathrm{E}-01$ & $2.148 \mathrm{E}-01$ \\
\hline & 25 & $7.490 \mathrm{E}+08$ & $2,696 \mathrm{E}+15$ & $9.663 \mathrm{E}-03$ & $1.208 \mathrm{E}-01$ & $1.961 \mathrm{E}-01$ \\
\hline \multirow{3}{*}{40} & 50 & $9.362 \mathrm{E}+08$ & $3.370 \mathrm{E}+15$ & $1.208 \mathrm{E}-02$ & $1.510 \mathrm{E}-01$ & $2.193 \mathrm{E}-01$ \\
\hline & 30 & $5.617 \mathrm{E}+08$ & $2.022 \mathrm{E}+15$ & $7.247 \mathrm{E}-03$ & $9.059 \mathrm{E}-02$ & $1.699 \mathrm{E}-01$ \\
\hline & 25 & $4.681 \mathrm{E}+08$ & $1.685 \mathrm{E}+15$ & $6.039 \mathrm{E}-03$ & $7.549 \mathrm{E}-02$ & $1.551 \mathrm{E}-01$ \\
\hline
\end{tabular}


The maximum sufficiency of the potential EGS reservoir was determined for three provident scenarios (based on the hourly peak power demand for Hólmavík - $855 \mathrm{~kW}$, given by the Westfjords Power Company (2016)): 25-, 30- and 50-years of expected exploitation (Sanyal et al. 2007, Lacirignola \& Blanc 2015). Moreover, taking into consideration the fact that the energy accumulated within the reservoir must at least cover the heating energy demand in Hólmavík over a given number of years, the dimensions (volume, area and radius) of the reservoir were determined. The required volume was calculated based on the transformed equation (1) and the formula is the following:

$V=\frac{E_{Z S}}{C_{p} \cdot \rho \cdot\left(T_{0}-T_{i}\right)}$

where:

$V$-volume of reservoir $\left[\mathrm{m}^{3}\right]$,

$E_{z s}$ - static resources of energy stored within a reservoir [J],

$C_{p}$ - specific heat of formation $\left[\mathrm{J} /\left(\mathrm{kg} \cdot{ }^{\circ} \mathrm{C}\right)\right]$,

$\rho$-formation density $\left[\mathrm{kg} / \mathrm{m}^{3}\right]$,

$T_{0}$ - mean initial formation temperature $\left[{ }^{\circ} \mathrm{C}\right]$,

$\mathrm{T}_{i}$-application injection temperature $\left[{ }^{\circ} \mathrm{C}\right]$.

Then, having the reservoir's volume, it was possible to determine the area of the potential reservoir, using formula (3). Since the reservoir was assumed to be a cylindrical shape, to calculate the maximum radius $(R)$ of the definite reservoir the equation for the surface area of a circle (4) was implemented. The aforementioned formulas are as follows:

$A=\frac{V}{d}$

$A=\pi \cdot R^{2} \rightarrow R=\sqrt{\frac{A}{\pi}}$

where:

$A$ - area of reservoir $\left[\mathrm{m}^{2}\right]$,

$V$-volume of reservoir $\left[\mathrm{m}^{3}\right]$,

$d$-thickness of reservoir [m],

$R$-radius of reservoir $[\mathrm{m}]$.

\section{The effect of computation}

The calculation based on the formula (1) has proven that thermal conditions in Iceland, even within low-temperature areas, are more than enough for EGS implementation. Static resources $\left(E_{\mathrm{ZS}}\right)$ for the analyzed reservoir in the vicinity of Hólmavík town were calculated to be about $222 \cdot 10^{15} \mathrm{~J}$, that is more than $62 \cdot 10^{9} \mathrm{kWh}$ (recovery rate equals to $1 \%)$. Excluding the changes in the reservoir's conditions, if the total exploitation of the reservoir was possible, the energy stored in HDR would be enough to cover Hólmavík town's heating energy demands for approximately 828 years.

The sufficiency of the designed reservoir was calculated for its three different lifetimes: 25, 30 and 50 years. Results are shown both in numerical and graphical form. The numerical outcomes (Tab. 3) include the sufficiency of the reservoir as well as its dimensions for different energy recovery rates over a given number of years. Nonetheless, the following chart (Fig. 3) illustrates the required reservoir radius and expected energy accumulated within such reservoir in various energy recovery rates.

\section{Discussion}

To sum up, analyzing the previously collected data concerning the Hólmavík town area, it can be claimed that in terms of geological issues, the implementation of Enhanced Geothermal System for heating purposes (low-temperature DH) is considered to be a good prospect for the future. As it was presented, the given area has a significantly high value of geothermal gradient, varying by location from $60^{\circ} \mathrm{C}$ to even $117^{\circ} \mathrm{C}$, thus there is still enough to establish the EGS technology (Brown et al. 2012). Also, the heat flow remains quite considerable, as it amounts to a value from the range of $101-150 \mathrm{~mW} / \mathrm{m}^{2}$. From the information obtained about the local lithology, it can be noticed that the lava layers prevalent within the Westfjords area are replete with vesicular and fractured in some parts, an important issue for the development of the EGS. Nevertheless, as its permeability remains quite low (i.e. about $2-5 \mathrm{mD}$ ), hydro-stimulation would be needed. In addition, the occurrence of dense basalt formation and numerous intermediate layers (sediments, mainly redbeds) can be valuable, as they might be considered cap rocks. Moreover, the results obtained during calculations show that there is enormous potential for the implementation of the EGS technology. 
The maximum potential of the energy stored within the definite HDR formation remains significant $-222 \cdot 10^{15} \mathrm{~J}$, that is about $278 \cdot 10^{6} \mathrm{~J} / \mathrm{m}^{3}$ of the above reservoir. Moreover, the required radius of cracking (Fig. 3) seems to be plausible. Altogether, the geology and temperature gradient that is expected to be obtained allows for developing a low-temperature district heating network. Nevertheless, as this study remains a rough estimation, for any further and more detailed consideration, it would be necessary to drill an exploratory well in the immediate vicinity of Hólmavík town and proceed with a more advanced study based on the dynamic behavior of the reservoir.

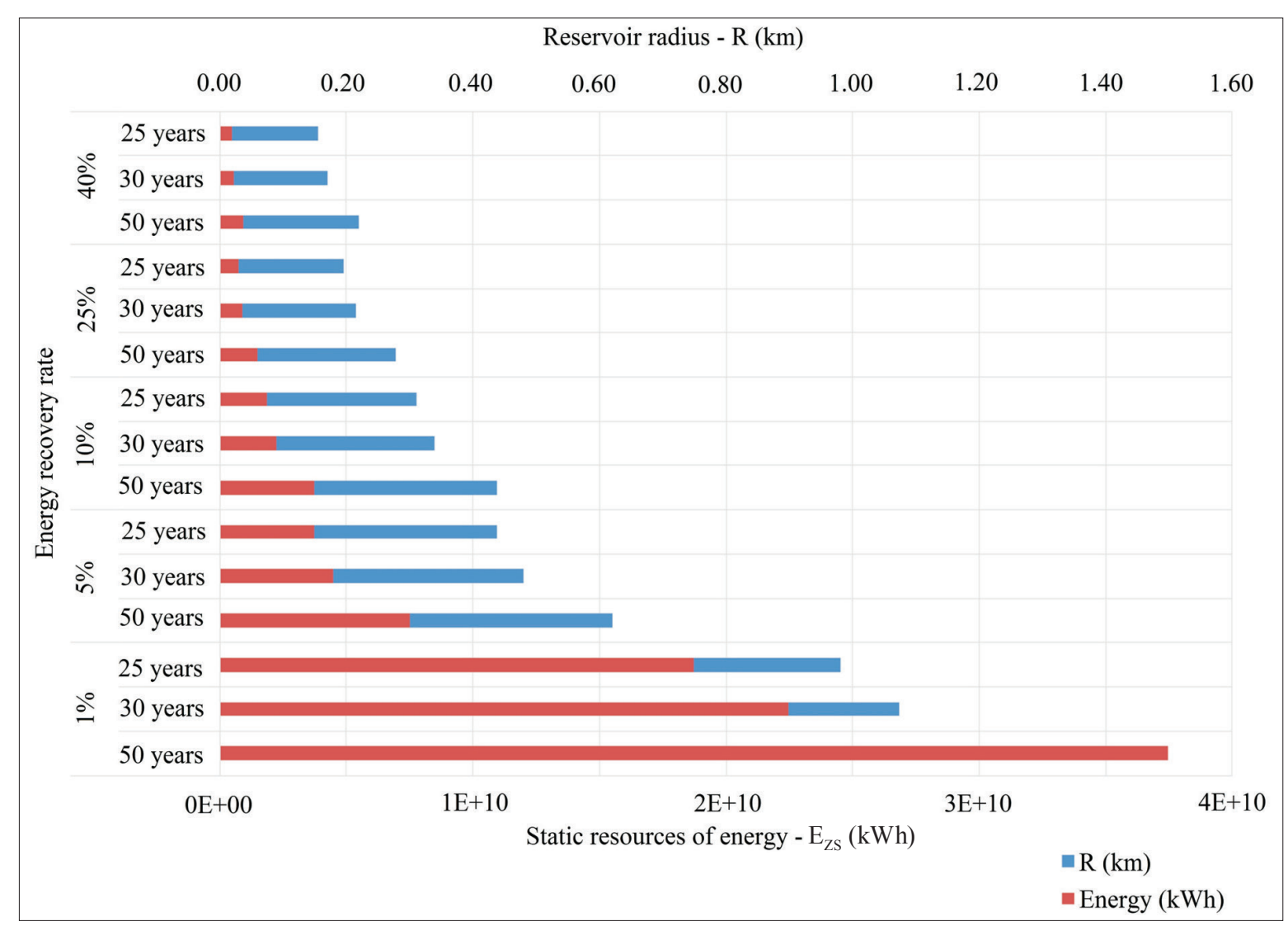

Fig. 3. Expected reservoir dimensions and required static energy resources

\section{CONCLUSIONS}

Considering mainly issues related to geological structure, it was found that Iceland has excellent conditions for the implementation of Enhanced Geothermal Systems. Low-temperature areas of the country are characterized by high, completely sufficient values of heat flux $\left(101-150 \mathrm{~mW} / \mathrm{m}^{2}\right)$ and geothermal gradient $\left(60-117^{\circ} \mathrm{C} / \mathrm{km}\right)$. Also, the properties of rocks within the analyzed area are considered sufficient for a HDR formation, which are relatively hot and have low permeability. At the same time, they are characterized by high porosity, but are of the closed type - vesicular, often re-filled and thus hydro-stimulation would be required. It is worth mentioning that residents of low-temperature areas in Iceland, mainly in the Westffords region, are very positive when it comes to implementing new technologies. Iceland today is one of the leaders in the utilization of geothermal energy, and in the case of investment in EGS, it could become completely independent from other energy sources (e.g. fossil fuels). Furthermore, the share of geothermal energy in the energy mix of the country could balance the share of hydropower. However, at this point, the question of the economic justification for the implementation of the EGS to produce heat, and with further development perhaps also electricity, remains inconclusive. 
The cooperation with Iceland, which remains one of the world's leading countries in the utilization of renewable energy resources, provides the possibility of developments in the field of geothermal energy, enriching participants with theoretical knowledge as well as practical skills. Since Iceland possesses enormous experience with the broad utilization of geothermal resources for different purposes, it remains an excellent example for countries such as Poland that are developing their geothermal energy sectors. The numerous exchanges that have been organized within the FSS Program contribute to the extensive nature of Polish-Icelandic cooperation. Many projects such as the one realized by Polish students in cooperation with employees of the Keilir Institute of Technology (Iceland), improve their qualifications and might bring several benefits for the domestic economy. Furthermore, as Poland also carries out research on the implementation of EGS in internal conditions, this project remains a significant issue.

The authors would like to thank Krista Hannesdottir and all the employees of the Keilir Institute of Technology for their cooperation within the FSS Program, the National Authority of Iceland for providing the necessary data and the employees of the Iceland Geosurvey for consultations. This paper was created as one of the results of the FSS Program - Scholarship and Training Fund Mobility Projects in Higher Education for the years 2015/2016, within the statutory work no. 11.11.140.321.

\section{REFERENCES}

Axelsson G., Gunnlaugsson E., Jónasson T. \& Ólafsson M., 2010. Low-temperature geothermal utilisation in Iceland - Decades of experience. Geothermics, 39, 4, 329-338.

Björnsson S., 2011. Geothermal Development and Research in Iceland. Information Brochure. Orkufstofnun, Reykjavik.

Brown D.W., Duchane D.V., Heineken G. \& Hriscu V.T., 2012. The Enormous Potential of Hot Dry Rock Geothermal Energy. [in:] Mining the Earth's Heat: Hot Dry Rock Geothermal Energy, Springer Science \& Business Media, 17-44.

Bujakowski W., Barbacki A., Miecznik M., Pająk L., Skrzypczak R. \& Sowiżdżał A., 2015. Modelling geothermal and operating parameters of EGS installations in the lower trassic sedimentary formations of the central Poland area. Renewable Energy, 80, 441-453.
Drabik A., Sowiżdżał A. \& Tomaszewska B., 2016. Doświadczenia Islandii w zakresie wykorzystania niskotemperaturowych zasobów energii geotermalnej. Technika Poszukiwań Geologicznych. Geotermia. Zrównoważony Rozwój, 1, 111-120.

Gancarz M., 2015. A characterization of the geothermal potential of the Muschelkalk deposits' location, with the prospective of its utilization in balneology and recreation (southern Poland). Geology, Geophysics \& Environment, 41, 4, 333-342.

Górecki W. (red.) et al., 2006. Atlas zasobów geotermalnych formacji mezozoicznej na Niżu Polskim [Atlas of geothermal resources of mesozoic formations in the Polish Lowlands]. Akademia Górniczo-Hutnicza im. S. Staszica, Kraków.

Górecki W. \& Hajto M., 2006. Klasyfikacje i metodyka oceny zasobów energii geotermalnej. [in:] Górecki W. (red.), Atlas zasobów geotermalnych formacji mezozoicznej na Niżu Polskim, Akademia Górniczo-Hutnicza im. S. Staszica, Kraków, 157-161.

Górecki W., Sowiżdżał A., Hajto M. \& Wachowicz-Pyzik A., 2015. Atlases of geothermal waters and energy resources in Poland. Environmental Earth Sciences, 74, 12, 74877495.

Haenel R. \& Staroste E., 1988. Atlas of geothermal resources in the European Community, Austria, and Switzerland. Verlag Th. Schaefer, Hannover, Germany.

Hurter S. \& Haenel R. (eds.), 2002. Atlas of Geothermal Resources in Europe. Office for Official Publications of the European Communities, Brüssel, Luxemburg.

ISOR - Iceland GeoSurvey, 2016. Official Project consultations. Reykjavik.

Korzec K., 2016. Hydrogeochemical characteristic of thermal waters in Bańska Niżna. Geology, Geophysics \& Environment, 42, 1, 85-86.

Kranz K., 2006. Geothermal energy in Iceland. Technische Universitat Bergakademie, Institute of Hydrogeology, Freiberg, Germany, [on-line:]: http://www.geo.tu-freiberg.de/oberseminar/os06_07/Kathrin\%20Kranz.pdf [access: 20.10.2016].

Lacirignola M. \& Blanc I., 2013. Environmental analysis of practical design options for enhanced geothermal systems (EGS) through life-cycle assessment. Renewable Energy, 50, 901-914.

Li H. \& Svendsen S., 2012. Energy and exergy analysis of low temperature district heating network. Energy, 45, 1, 237246.

McDougall I., Kristjansson L. \& Sæmundsson K., 1984. Magnetostratigraphy and geochronology of Northwest Iceland. Journal of Geophysical Research: Solid Earth, 88, B8, 7029-7060.

Muffler L.J.P. \& Cataldi R., 1978. Methods for Regional Assessment of Geothermal Resources. Geothermics, 7, 2-4, 53-89.

Olasolo P., Juárez M.C., Morales M.P., D’Amico S. \& Liarte I.A., 2016. Enhanced Geothermal Systems (EGS): A Review. Renewable and Sustainable Energy Reviews, 56, 133-144.

Orkustofnun, 2016. Orkutölur 2015. Orkustofnun, Reykjavik, [on-line:] http://os.is/gogn/os-onnur-rit/orkutolur_ 2015-islenska.pdf [access: 24.11.2016]. 
Ragnarsson Á., 2015. Geothermal Development in Iceland 2010-2014. [in:] World Geothermal Congress, 16-24 Apri 2015, Australia-New Zealand: proceedings, International Geothermal Association, Melbourne, 1-15, [on-line:] https://www.geothermal-energy.org/pdf/IGAstandard/ WGC/2015/01077.pdf [access: 27.10.2016].

Sæmundsson K., 1979. Outline of the geology of Iceland. Jökull Journal, 29, 7-28.

Sæmundsson K., 1999. Jaðhitaleit i Hólmavikurhreppi. Orkustofnun, Reykjavik.

Sæmundsson K. \& Björnsson S., 2002. Krikjubólshreppur: Borholumelingar og tillögur um framhald. Orkustofnun, Reykjavik, [on-line:] http://os.is/gogn/Greinargerdir/ Grg-OS-2002/KS-2002-07.pdf [access: 17.10.2016].

Sanyal S.K., Morrow J.W., Butler J. \& Robertson-Tait A., 2007. Is EGS Commercially Feasible? Geothermal Resources Council Transactions, 31, 313-322.

Sowiżdżał A., 2016. Possibilities of petrogeothermal energy resources utilization in central part of Poland. Applied Ecology and Environmental Research, 14, 2, 555-574.

Sowiżdżał A. \& Kaczmarczyk M., 2016. Analysis of thermal parameters of Triassic, Permian and Carboniferous sedimentary rocks in central Poland. Geological Journal, 51, $1,65-76$.

Sowiżdżał A. \& Semyrka R., 2016. Analyses of permeability and porosity of sedimentary rocks in terms of unconventional geothermal resource explorations in Poland. Geologos, 22, 2, 149-163.
Sowiżdżał A., Papiernik B., Machowski G. \& Hajto M., 2013. Characterization of petrophysical parameters of the Lower Triassic deposits in prospective location for Enhanced Geothermal System (central Poland). Geological Quarterly, 57, 4, 729-744.

Tester J., 2006. Energy recovered from Enhanced/Engineered Geothermal Systems (EGS). Assesment of impact for the US by 2050. DOE EGS Program Review, Massachusetts Institute of Technology, Colorado 18-19 July 2006.

Thordarson T., 2012. Outline of the geology of Iceland. [in:] Volcanism and the atmosphere: AGU Chapman Conference on Volcanism and the Earth's Atmosphere; Selfoss, Iceland, 10-16 June 2012, [on-line:] http://www.agu.org/ meetings/chapman/2012/bcall/pdf/Chapman_Outline_ of_Geology_of_Iceland.pdf [access: 4.10.2016].

Tomaszewska B. \& Hołojuch G., 2011. The pilot of geothermal water desalination installation in Poland. Geology, Geophysics \& Environment, 37, 2, 313-321.

Tómasson J. \& Arason P., 2000. Evidence for thermal mining in low-temperature geothermal areas in Iceland. $\mathrm{Ge}$ othermics, 29, 6, 723-735.

Wójcicki A., Sowiżdżał A. \& Bujakowski W. (red.) et al., 2013. Ocena potencjału, bilansu cieplnego i perspektywicznych struktur geologicznych dla potrzeb zamkniętych systemów geotermicznych (hot dry rocks) w Polsce. Państwowy Instytut Geologiczny - Państwowy Instytut Badawczy, Warszawa - Kraków. 